\title{
2 Records and archives documenting gross human rights violations
}

\section{The United Nations in action: the right to know and the fight against impunity}

Over the last 30 years, the ever-growing struggle against impunity and the extension of global justice have spawned new individual and collective rights. Since the end of the Cold War, the United Nations has put international legal mechanisms in place to stamp out impunity. The international criminal tribunals set up for the former Yugoslavia in 1993 and for Rwanda in 1994 were major steps in this direction and were further underpinned in 1998 by the adoption by the United Nations of the founding treaty of the International Criminal Court, as a permanent body with universal jurisdiction for judging those accused of genocide, crimes against humanity, crimes of aggression and war crimes.

This development was followed in 2005 by the UN World Summit of Heads of State and Government, which decreed that States had a "responsibility to protect" 7 their own populations and the right to embark on international humanitarian action or to intervene in the event of an imminent threat of genocide or gross violations of human rights.

In the 1980s, self-amnesty laws began to proliferate in Latin America in the name of peace and reconciliation, for example in Chile, Argentina and Uruguay. But amnesty is often just a way of burying the past and forcing people to "forget" the crimes perpetrated, at the expense of victims and their families. There was a period during which, for reasons of pragmatism, these laws were considered a necessary evil, but all this changed following pressure from human rights NGOs and the introduction of mechanisms by the UN Commission on Human Rights to outlaw impunity. In 1992, the Inter-American Court of Human Rights issued the reminder that "the State has the obligation to use all the legal means at its disposal to combat impunity . . . , since impunity fosters chronic recidivism of human rights violations and total defencelessness of victims and their relatives". ${ }^{8}$

The World Conference on Human Rights held in Vienna in 1993 supported this line of thinking by adopting the text of a Declaration urging the United Nations to step up its efforts to combat impunity and a Programme 


\section{Gross human rights violations}

of Action. ${ }^{9}$ The UN Commission on Human Rights then appointed a French magistrate, Louis Joinet, to the post of Special Rapporteur on matters relating to the impunity of the violators of human rights. The aim was to seek "to strike an unattainable balance between the former oppressors' desire for everything to be forgotten and the victims' quest for justice" (Joinet, 1997, p. 3). His report formed part of the process of implementing the Vienna Programme of Action.

The report lists the three rights to which victims should be entitled: the right to know, the right to justice and the right to reparation. It also adds, as a precaution, a series of measures aimed at guaranteeing the non-recurrence of violations. The report concludes by listing a set of principles for the protection of human rights through action to combat impunity that are given in appendix to the main body of the report (Joinet, 1997, Annex II).

The right to know is a condition sine qua non for exercising the right to justice and reparation. It is therefore the first right mentioned together with four supporting general principles:

The first of these concerns the inalienable right to truth, which is not only an individual but also a collective right:

Every people has the inalienable right to know the truth about past events and about the circumstances and reasons which led, through systematic, gross violations of human rights, to the perpetration of heinous crimes. Full and effective exercise of the right to the truth is essential to avoid any recurrence of violations in the future.

The second principle follows on logically from and is the counterpart of the first and is the State's duty of remembrance:

A people's knowledge of the history of its oppression is part of its heritage and, as such, must be preserved by appropriate measures in fulfilment of the State's duty to remember. Such measures shall be aimed at preserving the collective memory from extinction and, in particular, at guarding against the development of revisionist and negationist arguments.

The third principle concerns the victims' right to know: "Irrespective of any legal proceedings, victims, their families and relatives have the imprescriptible right to know the truth about the circumstances in which violations took place and, in the event of death or disappearance, the victim's fate".

The fourth principle is entitled "guarantees to give effect to the right to know" and concerns action to be taken in cases where the judicial institutions are found wanting: establishing extra-judicial commissions of inquiry and ensuring the preservation of archives pertaining to human right violations. 
Principles 13-17 relate to the preservation of and access to these archives. ${ }^{10}$ Penalties are to be applied to prevent destruction or falsification of archives, especially if this is for the purpose of ensuring the impunity of the perpetrators of human rights violations. Access to archives must be facilitated for victims and their relatives to enable them to claim their rights and for those implicated who request it for their defence. The courts and extra-judicial commissions of inquiry must have free access to archives. Specific measures must be put in place to protect personal records. Major progress was achieved in 1998, when the Commission on Human Rights endorsed these Principles, ${ }^{11}$ because it was the first time that a UN agency officially recognised the link between archives and the battle against impunity. But these principles remain guidelines, which have no force in law. They are a reference framework, the purpose of which is to help States in introducing their own effective measures for combatting impunity. They have, however, been firmly endorsed by decisions reached in the international criminal courts and have been a contributory factor in progress made towards stamping out impunity.

At the request of the Commission, these Principles were revised in 2005 by Diane Orentlicher, a U.S. citizen and professor of international law (Orentlicher, 2005). The main modifications concerned the scope of the obligations befalling States under international law. The sections on archives are now numbered 14-18. A detailed commentary on the archival dimension of this subject may be found in a document co-authored by Valentina Cadelo and Trudy Peterson (2018).

The right of victims and their families to truth and reparation was formally recognised in the International Convention for the Protection of All Persons from Enforced Disappearance adopted by the UN General Assembly in 2006. ${ }^{12}$ The Convention opens by affirming "the right of any victim to know the truth about the circumstances of an enforced disappearance and the fate of the disappeared person, and the right to freedom to seek, receive and impart information to this end". This Convention is consistent with the proposals made by both Louis Joinet and Diane Orentlicher.

The notion of the right to the truth was originally mooted in the Organization of American States well before any of the major international organizations took up the cause. The Inter-American Commission on Human Rights (IACHR) was the first to raise the issue of the right to truth in so many words as one of the rights that States must guarantee for more effective application of human rights in accordance with the American Convention on Human Rights (Rodríguez, 2017).

The first time that the Inter-American Commission on Human Rights mentioned the subject of the right to truth was in 1986, in its 1985-1986 annual report. It stated, in particular, that every society has the inalienable right to know the truth about past events, as well as the motives and circumstances in which aberrant crimes came to be committed, in order to prevent repetition of such acts in the future. At the same time, nothing must prevent victims' families from knowing what happened to their relatives. 
The importance of archives in the quest for truth was clearly stated for the first time at the United Nations in 2005 by the Commission on Human Rights. In its resolution on the right to truth, the Commission made reference to the updated version of the Joinet principles in stating that it was

convinced that States should preserve archives and other evidence concerning gross violations of human rights and serious violations of international humanitarian law to facilitate knowledge of such violations, to investigate allegations and to provide victims with access to an effective remedy in accordance with international law. ${ }^{13}$

At the request of the Human Rights Council, ${ }^{14}$ the Office of the United Nations High Commissioner for Human Rights carried out a first study on the right to truth in $2006 .{ }^{15}$ This was the subject of an updated report in 2007, following consultations with the States and NGOs. ${ }^{16}$ Paragraphs 58-70 of the study address the need to preserve archives and make them accessible in view of their importance in ensuring that reparation can be made for damage suffered by victims and for prosecuting those responsible for the atrocities perpetrated. These archives have an intrinsic value directly linked to the exercise of victims' rights, the workings of the courts and non-judiciary mechanisms for establishing the facts, preserving memory and history. They may be used as evidence, especially for publicly rehabilitating people convicted on political grounds, the right of families to know the location of their vanished relatives, the right to amnesty of political prisoners and the right of victims to reparation and compensation. They also enable individual nations to exercise their right to the integrity of their written memory and the right of individual peoples to know the truth about their past.

In a second report on the right to truth dated 2009, the Office of the United Nations High Commissioner produced a more detailed description of the best practices for exercising this right, with almost half of the document concerning archival practices with regard to blatant human rights violations. ${ }^{17}$ The report recommends reinforcing the national archival system as a fundamental stage in any transition process. It also insists on the vital need for countries to enact laws on access to these archives. It describes the different ways in which archives can be used as part of transitional justice processes, both for purposes of prosecution and the right to justice and for efforts to discover the truth and the right to know. It gives details of the types of document that can prove useful and insists on the need to preserve the records of national or international transitional justice institutions, which are essential to the nation and its history.

In 2011, at the request of the Council, the Office of the High Commissioner organised a seminar attended by experts from NGOs and truth commissions, magistrates and archivists, who had the opportunity to describe the lessons to be learned from international experience. This was followed 
in 2012 by a resolution adopted by the Human Rights Council on the right to truth, which was endorsed by the UN General Assembly in 2013. This resolution

encourages States that have not yet done so to establish a national archival policy that ensures that all archives pertaining to human rights are preserved and protected and to enact legislation that declares that the documentary heritage of the nation is to be retained and preserved. ${ }^{18}$

In 2011, the Human Rights Council decided to mandate a Special Rapporteur to study developments with regard to the right to truth. ${ }^{19}$ To justify this decision, it referred, among other things, to the International Convention for the Protection of All Persons from Enforced Disappearance, Article 24, $\mathbb{S} 2$ of which recognises that all victims "have the right to know the truth regarding the circumstances of the enforced disappearance, the progress and results of the investigation and the fate of the disappeared person". It also states that "each State-Party has to take appropriate measures in this regard". In addition, the preamble to the Convention affirms the "right to freedom to seek, receive and impart information to this end".

In 2012, the Council appointed Colombian human rights expert Pablo de Greiff to be Special Rapporteur on the promotion of truth, justice, reparation and guarantees of non-recurrence, tasked principally with gathering

relevant information on national situations, including on normative frameworks, national practices and experiences, such as truth and reconciliation commissions and other mechanisms, relating to the promotion of truth, justice, reparation and guarantees of non-recurrence in addressing gross violations of human rights and serious violations of international humanitarian law, and to study trends, developments and challenges and to make recommendations thereon.

Two of Pablo de Greiff's annual reports specifically mention archives. His 2013 report to the General Assembly addressed the subject of truth commissions (de Greiff, 2013). In it, he expressed his conviction that setting up commissions and National Archives was an excellent means of ensuring the right to truth and emphasised the importance of archives as a bulwark against denial and revisionism.

In his report on Spain, published in 2014, de Greiff (2014) recounted the problems faced by the victims of repression in Spain in their attempts to discover the facts, referring to the existence of classified documents with no clear criteria for release into the public domain and, therefore, inaccessible sine die, in accordance with an outdated official secrets act passed in preConstitution days. He also flagged up disparities in archiving practices from one administration to another or from one section to the other of the same 
administration, contradictory and inadequate regulations on access and the lack of government-level legislation on archives.

It was, however, the report published by Pablo de Greiff in September 2015 that was to represent the second major development for the world of archives, in terms of references to archives and records in official documents produced by the United Nations in connection with the defence of human rights. In line with the instructions of the Human Rights Council, this report was supposed to follow up and expand on Louis Joinet's Set of Principles for Combatting Impunity. However, unlike the JoinetOrentlicher report, where the similarities with the recommendations of the International Council on Archives were not the result of concertation, in this instance the UN rapporteur had talked with archiving professionals and exchanged information with them. This point is clearly established in the report when it refers to the methods adopted and the contacts established for its compilation: In September 2014, the Special Rapporteur, the International Committee of the Red Cross and the organization Swisspeace organised in Geneva an expert workshop entitled "Archives in the Context of the Right to Know" (de Greiff, 2015).

In his report (paragraph C of Section VI, Interventions in the cultural and the individual spheres), de Greiff maintains that

archives containing records of mass violations can contribute to prevention. Access to well-preserved and protected archives is an educational tool against denial and revisionism, ensuring that future generations have access to primary sources, which is of direct relevance to history teaching.

He goes on to admit

a lack of consistency in the disposition of archives of transitional justice mechanisms, including truth commissions. To address this gap, as a first step and as a result of a series of consultations with experts, the Special Rapporteur developed a set of general recommendations that builds on the right to know.

These recommendations are given in an annex with the title "Set of general recommendations for truth commissions and archives".

This annex to the report ${ }^{20}$ contains recommendations on the archives produced by truth commissions. These recommendations are of vital importance because many of these documents are almost completely inaccessible and the solutions proposed for their management so dissimilar. Once societies, still marked by the traumas of the past, are finally ready to confront reality, they need to be able to consult these records, even following disbandment of the truth commissions. The annex also includes recommendations about the need for these commissions to consult records during their investigations. Archives must therefore be preserved and properly managed 
by qualified professionals. Pablo de Greiff issues a reminder in his report that archival systems and public records management policies should constitute two further objectives to be targeted in any process of political transition towards democracy. He therefore urges the commissions to recommend the development of national archiving policies and the introduction of modern legislation on archives, access to information and data protection. He also recommends that the authorities endow their national and local archives with the resources they need to be able to function correctly and develop comprehensive systems also protecting the archives of non-governmental organizations and business archives. Both can be vital in relation to violations.

In the 2017 report to the UN General Assembly, the focus was on prevention and included a passage on archives and records: "Access to wellpreserved and protected archives is an educational tool to combat denial and revisionism, as important for history education as for dimensions of institutional reform" ${ }^{21}$ This sentence was repeated in the 2018 report, submitted by Fabián Salvioli, the successor to Pablo de Greiff. ${ }^{22}$

In July 2020, Salvioli presented his report (2020) Memorialization Processes in the Context of Serious Violations of Human Rights and International Humanitarian Law: The Fifth Pillar of Transitional Justice. In this report, archives are considered a key matter for every memory process, in particular the question of access to archives. Among other important considerations on archives, the report includes the following recommendation:

in order for memorialization processes to be effective, it is essential to protect the archives of State agencies and civil society organizations, especially those that work in the area of human rights. Archives should be accessible in accordance with established standards, and Governments should remove obstacles to such access.

The Office of the High Commissioner also tasked Trudy Huskamp Peterson with conducting an in-depth study into the issue of archives and the right to truth. Her findings were published in 2015 under the title "Ruleof-law Tools for Post-conflict States". ${ }^{23}$ In this, she gives practical advice on managing and using archives in post-conflict states or those in the process of transition to democracy. She describes the type of documents required for investigation purposes and for vetting and expurgation and runs through the problems typically encountered. At the Office of the High Commissioner for Human Rights, archives are now established as one of the pillars of its efforts to re-establish the rule of law in countries in the process of transiting towards democracy.

\section{Archives of security services of former repressive regimes}

In countries long subjected to repressive regimes, where citizens were denied their most basic freedoms, and faced with the task of negotiating the transition towards democracy, the archives of the former State 
security services are a classic example of the importance of records for the new authorities and their citizens. Records that were formerly one of the main weapons in the armoury of repressive States for crushing all forms of political, religious, racial or ideological dissent have now become key elements under rule of law for repairing the damage suffered by the victims of repression and purging those responsible for the atrocities perpetrated. The scale of the tragedies reflected in these archives is beyond belief: millions of people who disappeared were incarcerated or interned in camps; hundreds of thousands of deportees and, among the victims of repression, close on 80 million deaths directly or indirectly attributable to this phenomenon in the 20th century according to Milton Leitenberg (2006), while Eric Hobsbawm (1995) puts the number of people who "died by human decision" in the 20th century at an estimated 187 million (Hobsbawm includes persons killed in wars).

Horrors in such proportions were bound, in all logic, to leave traces, even though, for obvious reasons, many records were hastily destroyed when those in charge of security and intelligence sensed the way the wind was blowing and took steps to erase all evidence of their acts. This is what happened in South Africa and in Rhodesia (González Quintana, 1997). Interestingly, the sheer volumes of records evidencing all the atrocities committed still represented one of the main challenges facing archivists. Archives were an essential $\operatorname{cog}$ in the state machinery in regimes based on systematic repression. All these regimes kept close tabs on their citizens by harvesting information about purported ideological opponents to their totalitarian or dictatorial policies, compiling endless reports, creating networks of informants and encouraging denunciation. Similarly, groups with particular ethnic or racial origins were identified and kept under close supervision under racist or segregationist regimes. With such tight controls, mass imprisonment and executions and major population movements would have been impossible without extensive infrastructures and logistics (prisons, concentration camps, supplies, transport, etc.) plus the troops and police to snuff out even the slightest suggestion of protest or social unrest. These regimes were also reliant on the existence of a complicated network of political and law enforcement agencies manned by hordes of civil servants and collaborators, in other words, repressive bureaucracy at its finest.

Huge volumes of archives were produced in connection with political repression in such regimes, the classic example being the 180 linear kilometres of records accumulated by the Stasi in the days of the former German Democratic Republic (GDR), to say nothing of the 174,000 officers and collaborators or the 40 million people or more on its records. All this material is now under the responsibility of the Federal Commissioner for the Records of the State Security Service (Stasi) in Berlin. And while we may not have precise figures, we can safely say that the records of the former Soviet KGB must have amounted to very similar volumes. Other extensive collections of records from repressive regimes may be found in Brazil, Spain and Portugal, 
etc. Last but not least, public archives in South Africa were flooded with documents from the "apartheid" administration.

These examples go to show how important archives are for repressive authoritarian regimes. From this we can draw a first conclusion, which is that records of this nature must have existed under all such regimes and, if not transferred to the new authorities during the transition process, probably still exist somewhere. Lost files may suddenly resurface quite by chance years later, as in the case of the archives of Alfredo Stroessner's political police in Paraguay. These contained the records for Operation Condor, a coordinated campaign of political terror mounted by dictatorships in countries in the Southern Cone (Argentina, Chile, Paraguay, Uruguay, Bolivia and Brazil), which were discovered in 1992, languishing in a repository in the suburbs of Asunción, by Martín Almada, a lawyer, human rights activist, former dissident and political prisoner. In Argentina, the archives of the Intelligence Service of the Police of Buenos Aires Province (Dirección de Inteligencia de la Policía de la provincia de Buenos Aires - DIPBA) owe their survival in 1998 to the unrelenting efforts of NGOs and, since 2000, have been held in safekeeping by the Buenos Aires Provincial Memory Commission. Yet, in 1983, the de facto President, General Reynaldo Bignone, personally gave the order that all the records held by the armed forces containing evidence of their acts should be destroyed. ${ }^{24}$ In Part 2, Chapter 16 by Mariana Nazar, there is a deep analysis of the Argentina's case. In Chad, the archives of President Hissène Habré's political police were discovered in 2001 by Human Rights Watch, ${ }^{25}$ as described in Henri Thulliez' case study in Part 2, Chapter 4. Another example is that of the historical archives of the Guatemalan National Police, more than 7 linear kilometres of material believed lost for ever, which came to light in an abandoned warehouse in 2005. Admittedly, the records kept by these regimes tended to be so voluminous that covertly destroying them was bound to be a major challenge, witness the attempts made to do away with Stasi records in Berlin between December 1989 and January 1990, which were thwarted by the population, and similar developments in Moscow with the Lubyanka archives on 24 August 1991.

The archives of the police and intelligence services, the so-called archives of terror, to use the name under which they are known in Latin America, are public archives. They consist, for the most part, of records and files on individuals under surveillance, duty logs, registers and witness statements at times extracted under torture, but they also contain records seized by the authorities during raids on suspect organizations and political opponents. To manage all these holdings, there would appear to have been two main approaches.

The first of these is typified by Germany, where a national authority has been made responsible for preserving the archives of the now defunct agencies, as shown in Part 2, Chapter 10 by Dagmar Hovestädt. Much the same approach has been adopted in other former communist countries in Central 
Europe. Because these authorities have a similar purpose and objective, some of them decided to join forces in setting up the European Network of Official Authorities in Charge of the Secret Police Files (European, 2014). ${ }^{26}$ The key feature of this approach is that files are used to ferret out those involved in the repressions of the past and disqualify them from holding any form of public office in the future (Lustration). Depending on the country, the national authority may take different forms. Poland and Slovakia have Institutes of National Remembrance, Germany has a Federal Commissioner, Hungary has a Central Archives, the Czech Republic and Romania have Research Institutes or Centres and, last but not least, Bulgaria has a Committee. While the names may differ, these authorities all have essentially the same objectives.

Another feature of this approach is the development of specific legislation to govern the use to be made of these files and records. New institutions, such as Remembrance Centres or Archives, have emerged in other parts of the world and in countries, mainly in Latin America, that have managed to break free from right-wing totalitarian regimes or military dictatorships. These institutions were also set up for the purpose of managing the records of the police or State security services of former repressive regimes, for example the Buenos Aires Provincial Memory Commission, established to take charge of the records of the Province's Police and Intelligence Service, or the Commission for the Archives of the Struggle against Dictatorship in the State of Rio Grande do Sul in Brazil, set up to manage the records of the Department of Political and Social Order (DOPS). The fundamental difference between these cases and those of former communist countries lies in the size and scale of the documents held: while archives of Central and Eastern European countries are remarkable for their sheer volumes, those in Latin America tend to be thin on the ground.

The second approach consists of consigning the archives of the State security services of former repressive regimes to the National Archives. The best illustration of this approach is Portugal, where records were first commandeered by the Commissions responsible for winding up these services in the immediate aftermath of the 1974 Carnation Revolution, before being transferred to the National Archives to be used by the courts and in the expurgation process. Similar arrangements occurred in Brazil, where the records of the National Security Council, the General Investigations Commission (Comissão Geral de Investigações) and the National Information Service (Serviço Nacional de Informações) were transferred to the National Archives when President Lula da Silva was in office. ${ }^{27}$ Another example is that of Spain, where the archives of General Franco's Intelligence Services were initially consigned to the Civil War Section of the National Archives. Since then, the section has changed name and the archives have been put under the umbrella of the Historical Memory Documentation Centre, while still having the same administrative reporting channels and the same links to the Spanish National Archives (Sub-Directorate General of National 
Archives). The case of the records of Alfredo Stroessner's secret police ("La Técnica") in Paraguay, which came to light by chance in 1992 during legal proceedings, is rather unusual. They were taken in charge by Paraguay's Supreme Court, where they are still managed by the Human Rights Archive and Documentation Centre.

The historical archives of Guatemala's National Police (AHPN) are another interesting example. These were discovered completely by chance, which explains why they were initially placed under the responsibility of the authorities that located them, in other words, the Office of the Ombudsman (Procurador de derechos humanos), despite the fact that they were not in the Office's actual possession because they remained the property of the Ministry of the Interior. The courts had ruled that the PDH would simply be allowed to consult them and manage them for use in its enquiries. With the help of a number of non-governmental organizations and volunteers, the PDH team then set about the difficult task of recovering these documents for use in chasing the truth, punishing those guilty of human rights violations and providing due reparation for victims. The international aid would be extended even when these records were officially transferred to the General Archives of Central America (Archivo General de Centro América - AGCA) in 2009 as required by the legislation on National Archives in force in Guatemala (González Quintana, 2019a).

In practice, these records constitute a special case, the like of which cannot be found anywhere else in the world, for two reasons: the first being the government's patent disinterest in them and the second the fact that they were exclusively funded by grants from development aid agencies in different countries under the banner of the United Nations Development Programme (UNDP). While the Archives remained answerable administratively to the Ministry of Culture (and previously to the PDH) for more than 13 years of their existence, they were managed more as a non-governmental organization than as a public service. They received no funds from government and their involvement in defending human rights went far beyond the normal role of a National Archive, their primary function being to hunt out cases that could be brought to trial and provide input for the public prosecutors and PDH investigators. But this state of affairs turned out to be untenable in the longer term, especially at a time when the country was faced with the difficulties caused by the changes underway under President Jimmy Morales that culminated, in 2019, with a change of political direction. The result was that the Ministry of Culture is now fully responsible for these archives, albeit following major culling, and for footing the corresponding bill, all international aid and the agreement with the UNDP having been summarily terminated. The documentary fonds of the Historical Archives of the Nation is now an integral part of the AGCA, this time not only in name. This development signalled the end of an experience unparalleled in other parts of the world, an example of archiving activism, the extent and limits of which deserve analysis. The case of Guatemala begs the question 
of whether it is really possible for the records of a state agency, such as the National Police, to be independently managed by groups of militant professionals supported by human rights defence organizations and through international cooperation. How long can such an arrangement last and what limits should there be to funding? Seen from the other end of the telescope, the real question is whether it should be incumbent on the State to take responsibility for preserving and providing access to such documents. Is the Guatemalan Government capable of assuming this responsibility? There is no easy answer to these questions, in particular in a country such as Guatemala, which has never had clearly defined, robust and consistent policies with regard to memory. In Part 2, Chapter 17, Kirsten Weld's offers plentiful information about this extraordinary tale. ${ }^{28}$

One thing that appears clear is that in a country like Guatemala, which has no specific institution similar to those in Germany, the Czech Republic, Argentina or other countries to manage the records inherited from the now defunct agencies of repression and make them available to the transitional justice authorities, and which has no clear policies with regard to tracking down the people responsible and making reparation for the atrocities perpetrated, the only valid option is to turn to the National Archives for their safekeeping, following the examples of Portugal, Brazil or Spain. This way these records will be preserved and kept in accordance with accepted professional standards and best practices. In 2009, it seemed that this was the option selected by Guatemala, but it then patently demonstrated its inability to follow through. In 2019, the AHPN was apparently forcibly transformed into an agency answerable to the government with all the attendant uncertainties that this entails. This being the case, can we really question the ability of the powers-that-be to appoint or dismiss the Head Curator or senior managers of this institution? Can we refute their capability in deciding on employee numbers and the conditions of their recruitment to the civil service dealing with these documents? All we can do is demand that the authorities act in the proper interests of the society they represent and that they should recruit staff according to professional criteria. Should they fail to do so, they should be held accountable (González Quintana, 2019b).

In some cases, one of the arguments for destroying records of a former repressive regime was to prevent their indiscriminate use by the police or the army in a democratic society, especially in countries where transition had been a peaceful or "pacted" process. The aim was to make sure that they could not be used, now or in the future, to abuse human rights. This is what happened in Greece, where the new government ordered records to be destroyed on completion of the expurgation process, on the grounds that it was time to shake off the past or because they contained misleading information that could be reused (González Quintana, 1997). But eliminating these archives once and for all further complicates the task of recording the history of the particular period, the only sources then being individual and, probably, subjective accounts. In the end, it is the victims and future 
generations that are the losers. The moral debate around the preservation of these holdings culminated in a recommendation from the experts in favour of keeping them to protect victims' rights to rehabilitation or reparations and enable the courts to rule on responsibilities.

These records are important because they bear witness to the past and to history and because they can enable victims to exercise their rights. The risk of a return to despotic practices can be obviated through international safeguards to protect the archives of repressive regimes by applying for their inclusion in the international Register of UNESCO's Memory of the World programme. Indeed, in its final report, the working group set up in 1995 by the International Council on Archives and UNESCO to examine these issues proposed that documentary fonds of this kind be included in this Register. As shown in the Introduction to this book, this is exactly what happened during the years 2003-2011.

During the transition processes, it was therefore considered vital by victims associations and human rights organizations to establish where records of this nature were located so that they could be handed over to the new democratic authorities and included in their archiving systems, together with suitable legal and physical safeguards and regulations governing their use. The idea was that this would make it easier for victims to obtain access to their personal files and for the courts, truth commissions and government agencies requiring proof to get hold of the records required to enforce the new democratic laws (on rehabilitation, amnesty, restitution, compensation, etc.). But all this is naturally contingent on major changes being made to the legislation in force.

\section{The archives of human rights NGOs}

One of the most striking phenomena of the 1980s was the arrival of civil society organizations on the international scene. In Latin America, these organizations campaigned against the self-amnesty laws that made it impossible to prosecute the perpetrators of violations and effectively introduced the principle of impunity. The Mothers and Grandmothers of the Plaza de Mayo in Argentina were among the first to push for information about the disappearance of their children and to campaign for the return of the so-called stolen babies to their real families. Their movement, which began in 1977, had a huge effect on Southern Cone and Central American countries. The Latin American Federation of Associations for the Relatives of the Detained and Disappeared (FEDEFAM), formed to raise the movement's profile, played a crucial role in bringing this tragedy to the world's attention (Joinet, 2002, p. 115). In the Mediterranean Basin, for example, 26 associations from 12 countries joined forces in a network around the EuroMediterranean Association against Enforced Disappearances (FEMED) with the goal of restoring truth and justice in the case of tens of thousands of enforced disappearances recorded in the countries concerned. 
In places where the archives of police and intelligence services have been deliberately destroyed, "cleansed" or hidden by officials determined to erase all traces of the crimes perpetrated or where the authorities refuse access to these records, the only alternative is to find other sources of information to establish proof of violations. And the archives of civil society organizations, of associations of the families and relatives of victims and survivors and of organizations for the defence of human rights offer valuable yet vulnerable alternatives.

Their records are also interesting on other grounds, for even when police files are not destroyed, they have to be used with care, because their impartiality is open to doubt and they may contain deliberately misleading information. It is therefore vital to be able to consult the archives of the NGOs in the hope of arriving at the truth. This is particularly the case in Latin America, for example in Argentina, Chile and Peru, where most of the records produced in the days of repression have gone missing, in contrast to those of countries in Central and Eastern Europe. Anne Pérotin speaks of a "lost continent of archives, the continent of military archives" (continent d'archives perdu, celui de la sécurité militaire) (Pérotin-Dumon, 2007, p. 86). While some documents may occasionally resurface and whole fonds of archives may, as we have already seen, suddenly reappear, such occurrences remain the exception.

Civil society organizations have the dual role of defending the victims and denouncing unlawful, political or military violence involving the State. Victim support associations tend to start out by covertly collecting information and personal testimonies for later use in proving the abuses endured by victims. The International Convention for the Protection of All Persons from Enforced Disappearances is a binding text that makes enforced disappearance a crime against humanity and therefore not subject to statutory limitations. ${ }^{29}$ The right of families to know the truth has no time limit and takes precedence over the right to justice, which expires on the victim's death. Families cannot achieve closure if they do not know where their loved ones are buried and are haunted by the need for proof that they are truly dead. To justify their actions when denouncing violations, the NGOs painstakingly pursue their investigations and analyses of the facts they have successfully collected. They produce files to help trace the bodies of missing persons, draw up lists of names and places, mass burial grounds, etc. and crossreference data with the information obtained from personal testimonies.

These NGOs produce various sorts of records depending on whether they are defending detainees or looking for missing persons:

1 Victim files containing all the documents collected to prove the existence of the missing person: birth certificate, family register, school reports, identity documents, health records, graduation certificates, private correspondence, mementos, photos and letters of the victim, personal testimonies, medical certificates and death certificate. 
2 Statements and claims filed by victims, documents lodged by lawyers, individual or collective demands for habeas corpus submitted by lawyers, and testimonies from survivors about the circumstances of repression. These first two categories may be used as evidence in court and the records concern named individuals. The data they contain are therefore sensitive.

3 Documents bearing witness to their communication efforts to prevent victims from being forgotten and put faces on victims: press releases and press kits relating to protest marches and campaigns staged to alert and stir up national and international public opinion, lists of victims and secret detention centres, posters, brochures, banners, pennants, placards, radio programmes and broadcasts, for example in Peru where the aim was to overcome the sense of isolation felt by Andean peasant farmers (Pérotin-Dumon, 2007, p. 70).

4 Documents targeting foreign nations and international intergovernmental and non-governmental organizations to build up awareness, create a wall of protection and report the facts, information transmitted to embassies, reports from religious organizations to the World Council of Churches, assignments carried out by Amnesty International and the Organization of American States (Pérotin-Dumon, 2007, pp. 65-66).

5 Sound or audiovisual recordings, oral testimonies collected from witnesses at the time or after the event.

All this material is unique and particularly at risk in the sense that the victim support associations often had to rush to collect information and personal testimonies in the utmost secrecy for later use as proof in cases of abuse. Long-term preservation was never one of the priorities of the activists and volunteers operating in repressive regimes, who had to keep changing addresses because of the threats hanging over their heads and the raids conducted on their homes. Documents could easily go missing or be lost, for want of resources or simply through carelessness, with these organizations being focused more on immediate and emergency action than on long-term preservation.

In addition, activists aware of the need to hold on to evidence tend to treat the papers in their possession as material for individual remembrance, with the risk that fonds, or collections of documents, may be split up. They often confuse documentation with archives and therefore treat archival records like documents in the sense that they are so obsessed with the content and its importance that they tend to forget the context in which the material was produced, which then makes it more difficult to interpret. If the organization is disbanded, there is the very real likelihood that records will be taken home by the people in charge, for whom they are almost like family documents, long stashed away, which further exacerbates the risks. Not only are they often fragile and in poor condition, but they also take a variety of forms. And it is not only posters, tracts, publications, photos, 
audio and visual materials and other objects that are vulnerable. There is the added complication of born digital records, databases and websites, which need regular updating. Failure to do so could prove fatal now as computers are in such general use.

These records represent a threat to the authorities in repressive regimes and it is not unusual for them to be confiscated or destroyed. The computer files of the Russian association Memorial, which offers legal and financial aid to Gulag victims and carries out research into past political repression, were seized by the police in 2008, which walked off with hard disks containing huge volumes of data about crimes perpetrated under Stalin. In Chile, the archives of the Vicaria de la Solidaridad (Vicariate of Solidarity) came under systematic attack and the Head of its Analysis Department, José Manuel Parada, was even assassinated in 1985 (Pérotin-Dumon, 2007, p. 77).

Chile is not the subject of a case study in this book, but it is interesting all the same in that, in contrast to Argentina, the Catholic Church was firmly behind the NGOs, the Vicariate being the most important example of its involvement. This diocesan agency was manned by some 100 employees, lawyers, social workers and researchers and a network of several thousand people and, while the dictatorship was in power, provided legal and administrative assistance to 49,000 victims and their relatives. Its lawyers conducted investigations that the police and the courts refused to undertake and took legal action on behalf of victims' families. The Vicariate acted as a news agency circulating information outside Chile and published a biweekly magazine distributed nationwide. Its archives are the largest human rights holdings of the whole Latin American continent with a total of 700 linear metres of records (Pérotin-Dumon, 2007, p. 54).

The Church was also engaged in victim defence in Brazil and Guatemala. "Brazil, Never again" (Brasil Nunca Mais), ${ }^{30}$ a project supported by the World Council of Churches, managed to collect thousands of depositions and documents on the country's military dictatorship (1964-1985) that made it possible to identify the torturers. Copies of these archives are held at the Center for Research Libraries in Chicago and at the World Council of Churches in Geneva (Groppo, 2012). In Guatemala, the Human Rights Office of the Archdiocese of Guatemala (Oficina de Derechos Humanos del Arzobispado de Guatemala) has placed all the documents it issued and collected, including those produced during the "Recovery of Historical Memory" project (Recuperación de la Memoria Histórica - REMHI) in the safekeeping of the Memory Centre of Monsignor Juan Gerardi (Centro de Memoria Monseñor Juan Gerardi).

In countries that have re-established democratic regimes, it is difficult for the State to take action to protect NGO archives, as these are private holdings. Records often concern named individuals and are therefore classed as sensitive, and NGOs are hesitant to transfer them to public archives, which they regard with mistrust. However, in recent years, a number of heritage 
associations have appeared on the scene and major progress has been made in the way archives are handled: in Argentina, the Memoria Abierta association, which is an alliance of nine victim and human rights defence associations, and in Chile, the Vicariate Foundation, have both started applying professional principles to their working methods and have become benchmarks for their peers.

NGOs have made key contributions to efforts to exercise the right to justice by supplying the truth commissions and courts with the reliable and compelling data they were able to obtain through their outreach and direct contacts with witnesses. Their archives are extremely valuable in helping to establish the facts, because the information was often recorded in the immediate aftermath of events. The records of the Vicariate in Chile were, for example, used by the Valech Commission on Political Imprisonment and Torture, which was given access to some 20,000 files (PérotinDumon, p. 84).

\section{Archives of International Tribunals and Truth Commissions}

While international tribunals and truth commissions are constantly chasing the records they need for their work, they in turn produce records of vital importance in understanding past events, many of which are oral depositions obtained during trials, in the case of the courts, or hearings, in the case of the truth commissions. These tribunals and commissions have one thing in common, namely that as temporary structures for delivering transitional justice, they are systematically faced with the problem of what to do with their own records, when they come to the end of their remit.

We have already spoken of the importance attached in 2015 by Pablo de Greiff to the information that truth commission archives can provide for other purposes than their own. Pablo de Greiff insists on the need for these records to be made accessible, provided that this does not infringe nondisclosure agreements reached with victims or perpetrators of violations only prepared to make statements under this condition. But, for his recommendations on the use of these archives to be possible, it is first necessary to find a solution to the problem of ensuring the preservation and management of this documentary heritage. Where truth commissions are concerned, the situation differs radically from one case to another.

Commissions enjoying the support of the United Nations, such as the Guatemala Historical Clarification Commission (Comisión para el Esclarecimiento Histórico de Guatemala), transferred their archives to the UN Headquarters in New York on completion of their work and publication of their final report. The records were then to remain classified for 50 years. This inaccessibility was not the only problem. There was also the downside that all this material providing irreplaceable information about a nation's past was taken out of the country. A similar situation occurred with the archives of the El Salvador Truth Commission. 
In cases where commissions owe their creation to the national authorities, the solutions proposed for their records also varied widely.

A first option was to transfer these records to the National Archives. This is what was decided in South Africa by the Truth and Reconciliation Commission headed by Archbishop Desmond Tutu, in line with the recommendations of its final report. In Part 2, Chapter 2, Graham Dominy offers us a detailed overview of events in South Africa. The same approach was adopted for the archives of Brazil's National Truth Commission (Comissão Nacional da Verdade). Once the Commission had completed its work, its documentary fonds were transferred to the National Archives. In this publication, Aluf Elias offers, in Part 2, Chapter 15 , a case study with regard to these archives. In Tunisia, the Truth and Dignity Commission also handed its archives over to the National Archives on completion of its mandate, though not without controversy, as outlined by Adel Maïzi in Part 2, Chapter 3.

Another option consisted of transferring commission records to one of the new archival institutions set up to help come to terms with the country's troubled past and enable this material to be used by the courts or victim reparation schemes. This is what happened with the archives of the National Commission on the Disappearance of Persons (CONADEP) created in Argentina in 1983 under President Raul Alfonsín in the postmilitary dictatorship period, which were later transferred to the National Archive of Remembrance set up in 2002. These records were vitally important in the legal action taken following the abrogation of the so-called Due obedience and Full stop laws passed during Nestor Kirchner's tenure as President.

In Chile, the archives produced by the different truth commissions are held in safekeeping by the Museum of Memory. These range from those of the original Truth and Reconciliation Commission, chaired by Raul Rettig and set up under President Patricio Aylwin, to those of the National Commission on Political Imprisonment and Torture chaired by Monsignor Sergio Valech via the National Reparation and Reconciliation Corporation under its President, Alejandro González Poblete. The Museum was created under the presidency of Michelle Bachelet to look into the country's violent past. The fonds is, however, only accessible to governmental human rights organizations.

On completion of its mandate and delivery of its final report, Peru's Truth and Reconciliation Commission decided to transfer its archives to the Public Defender (Defensoría del Pueblo), an institution set up in 2004 by the Information Centre for Collective Memory and Human Rights (Centro de Información para la Memoria Colectiva y los Derechos Humanos), where they are still held today. It was this centre that was tasked with circulating the archives of Peru's Truth Commission to public organizations, the families of victims of internal armed conflict, universities and those keen to discover the truth about events in Peru during the period 1980-2000. Part 2, 
Chapter 14 by Ruth Elena Borja Santa Cruz focuses on the subject of the archives of the Peruvian Commission.

One particularly striking example is that of Liberia's Truth and Reconciliation Commission. Once it had completed its work, the government in office was not in a position to take charge of the Commission's archives and decided, as a result, to send them for safekeeping to the Georgia Institute of Technology in the United States (Svärz, 2009).

The problems arising in connection with production of this type of documentary fonds and the alternatives for their management have been analysed in depth by Trudy H. Peterson (2005).

Temporary tribunals set up in post-conflict situations, at times as a result of resolutions voted by and directly linked to the United Nations, produce sets of documents that are extraordinarily valuable for remembrance in the countries concerned, in both case law and content terms (Kaye, 2014). The Special Tribunals for the former Yugoslavia and Rwanda created as a result of resolutions voted by the UN Security Council, the Tribunal for Sierra Leone that owed its creation to an international treaty, the Tribunals for East Timor and for Kosovo set up by UN Missions are also cases in point. The temporary nature of these institutions is an invitation in itself to think ahead to more permanent solutions, because the material they produce constitutes archival fonds with obvious informational value, which should be ample justification for their permanent preservation.

Not only did these temporary tribunals collect vast quantities of key documents in their search for written proof for use by the prosecutors but, during their sittings, they also churned out large numbers of records containing invaluable details of the events that occurred. Two iconic examples of this are the series of video recordings kept in the Archives of the Special Tribunal for Rwanda (Hunt, 2011) and the Gacaca Archive, which is the subject of Part 2, Chapter 5 by Peter Horsman.

The real issue here is where and under what authority archives should be kept once the tribunals have been disbanded. One possibility would be to entrust them to the care of a new agency to be set up at the headquarters of the International Criminal Court in The Hague, which could be tasked with the long-term preservation of all the archives produced by temporary special tribunals. Another alternative would be for those produced under the auspices of the United Nations to be transferred to the archives of the UN Office at Geneva. A third possibility could be to entrust them to the corresponding National Archives. This last option would probably be the most suitable, once the records have been used for all the legal and administrative purposes for which they were initially intended, because they would thus remain an essential part of the memory structures of the countries concerned. This would depend to a large extent on these countries actually owning the material produced and, more particularly, on the capacities and guarantees offered by the transition processes that follow 


\section{Gross human rights violations}

the special tribunals (Peterson, 2006). This solution would, however, not work in the former Yugoslavia, because the archival institution created there holds records relating to the different countries that have emerged from the disintegration of the old federation. At all events, the fate of these archives continues to remain an issue yet to be definitively resolved. 